\title{
PARADIGMA KONTEMPORER SISTEM PEMBELAJARAN AL QUR'AN \\ PADA ANAK USIA DINI \\ DI LEMBAGA TAHSIN QUR'AN KAUQOY PRIVATE
}

\author{
Nur Shofiyah \\ Pascasarjana UIN Sunan Ampel Surabaya \\ nurshofiyab1897@gmail.com \\ Masruchan \\ Pascasarjana UIN Sunan Ampel Surabaya \\ masruban@uinsby.ac.id
}

\begin{abstract}
Abstrak
Al-Qur'an sebagai kalamullah mengandung asas pengajaran karena mencakup ajaranajaran Islam yang menata kehidupan kaum muslimin dalam segala aspek di dunia dan akhirat. Pemahaman al-Qur'an terutama bagi anak harus dimulai sejak dini melalui kegiatan membaca dan menulis yang dilanjutkan dengan memahami ajaran agama Islam secara bertahap. Namun faktanya, sistem pembelajaran Al Qur'an terutama bagi anak usia dini masih monoton dan kurang menarik karena masih menerapkan paradigma pembelajaran yang berpusat pada pengajar. Penelitian ini bertujuan untuk mendeskripsikan sistem pembelajaran al-Qur'an di lembaga Tahsin Qur'an Ka'Uqoy Private dengan jenis penelitian kualitatif deskriptif dan menggunakan teknik pengumpulan data observasi, wawancara, serta dokumentasi. Hasil penelitian menunjukkan bahwa sistem pembelajaran al-Qur'an di lembaga Tahsin Qur'an Ka'Uqoy menerapkan paradigma konstruksionisme dengan hanya menggunakan satu peraga yaitu alat indera melalui ragam interaksi dengan lingkungan sekitarnya seperti melihat, mendengar, menyentuh, dan merasakannya. Melalui pengaktifan indrawi, seorang anak bisa membangun gambaran dalam dunia belajarnya. Lembaga ini telah mencetak pengajar yang mampu mengajarkan Al-Qur'an dengan mudah untuk difahami terutama bagi anak usia dini dengan cara ikut terlibat langsung dalam mencerna, mengolah, mengalami, memahami, merasakan dan mempraktikkan isi kandungan Al-Qur'an dengan fun learning sehingga para anak usia dini lebih mudah dalam menangkap ilmu AlQur'an dan menerimanya dengan senang hati.
\end{abstract}

Kata Kunci: Al-Qur'an, Lembaga KaUqoy Private, Metode Pembelajaran 


\section{Nur Shofiyah dan Masruchan}

\section{Abstract}

Al-Qur'an as kalamullah contains teaching principles because it includes Islamic teachings that organize the lives of Muslims in all aspects. Understanding the Qur'an, especially for children, must start early through reading and writing activities which are continued by gradually understanding the teachings of Islam. However, the fact is that the learning system of the Qur'an, especially for early childhood, is still monotonous and less interesting because it still applies a teacher-centered learning paradigm. This study aims to describe the al-Qur'an learning system in the Tahsin Qur'an ka'Uqoy Private institution with a descriptive qualitative research that uses some data collection techniques. The results showed that the al-Qur'an learning system in the tahsin Qur'an ka'Uqoy institution applies the constructionism paradigm by using only an instrument namely the senses through various interactions with the surrounding environment such as seeing, hearing, touching, and feeling it. Through sensory activation, a child can build a picture in the world of learning. This institution has produced teachers who are able to teach the Qur'an easily to be understood, especially for early childhood by being directly involved in digesting, processing, experiencing, understanding, tasting and practicing the contents of the Al- The Qur'an with fun learning so that early childhood can more easily grasp the knowledge of the Qur'an.

Keywords: Al-Qur'an, Private Ka 'Uqoy Institution, Learning Method 


\section{Pendahuluan}

Al-Qur'an dan pembelajarannya ialah usaha yang dilakukan secara sadar dari ustadz atau ustadzah pendidik terhadap peserta didik untuk belajar Al-Qur'an. Dengan menggunakan berbagai cara seperti membaca, menulis dan dapat mengetahui dan mempraktikkan membaca terhadap hukum bacaan yang terdapat dalam ayatayat Al-Qur'an. Dan dengan ini peserta didik sudah bisa belajar dan terdidik karena adanya usaha dan waktu. hal ini paling penting adalah pembentukan karakter melalui keberhasilnya sistem pembelajaran tersebut. Allah sendiri sudah menjelaskan di dalam Al-Qur'an surat al-maidah ayat 15-16

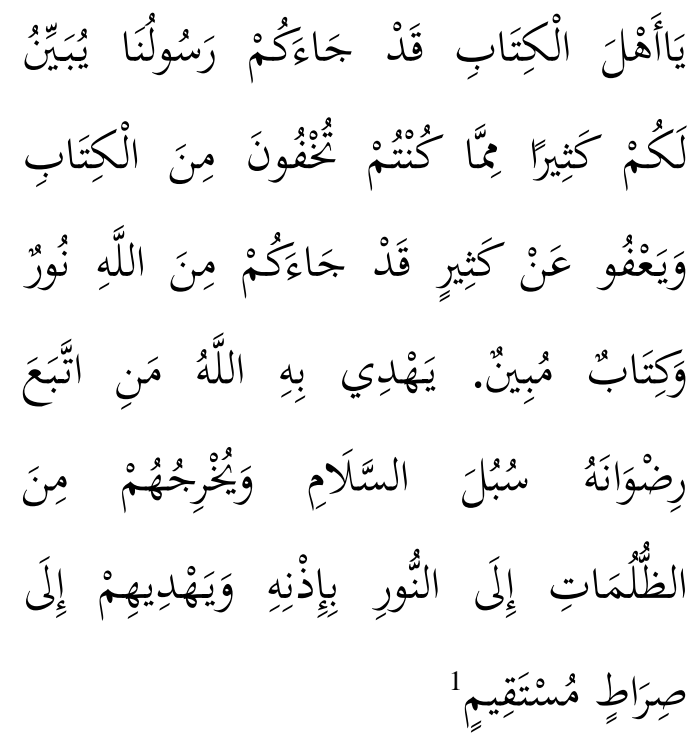

"wahai abli kitab! Sungguh, Rasuk kami datangkan kepadamu, menjelaskan kepadamu banyak hal dari isi kitab yang

${ }^{1}$ Departemen Agama RI, Alqur'an Dan Terjemahnya (Jakarta: Kemenag RI, 1998), 110. kamu sembunyikan, dan banyak pula yang dibiarkannya. Sungguh, telab datang kepadamu cahaya dari Allah, dan kitab yang menjelaskan. Dengan kitab itulah Allah memberi petunjuk kepada orang yang mengikuti keridhan-Nya ke jalan keselamatan, dan Allah menyelamatkan orang tersebut dari kegelapan gulita kepada cabaya dengan izin-Nya dan menunjukean kejalan yang lurus".

Al-Qur'an turun sebagai mendidik atau membimbing manusia mengarah pada keselamatan, dan mengangkat manusia dari hal yang terlarang menuju yang di perbolehkan agar mendapatkan petunjuk supaya mereka tetap pada jalan yang lurus. ${ }^{3}$

Rendahnya kualitas pembelajaran di Indonesia secara tidak langsung ditunjukkan oleh rendahnya kualitas pendidikan. Rendahnya kualitas pembelajaran terjadi dapat dilihat dari rendahnya kualitas pelajaran yang diberikan sang guru. Sebagai agen informan pelajaran, guru adalah pegangan utama untuk keberhasilan seorang anak didik. Jadi, kemampuan dan keberhasilan dalam berkreasi dan kreatif untuk memilih atau menggunakan strategi dalam pembelajaran

${ }^{2}$ Departemen Agama RI, 110.

3Prosiding Al, Hidayah Pendidikan, And Agama Islam, 'Implementasi Metode Pembelajaran Alquran Bagi Santri Usia Tamyiz Di Kuttab AlFatih Bantarjati Bogor Dosen Prodi Pendidikan Agama Islam Stai Al Hidayah Bogor A. Pendahuluan Alquran Menurut M. Sarbini Adalah Kalamullah S. W. T. (Kata-Kata Allah S. W. T), 1, 179-91. 
adalah faktor penting yang akan mengubah dan mempengaruhi keberhasilan pembelajaran yang ada di Indonesia.

Itulah mengapa pentingnya SDM yang berkemampuan tinggi dan mampu dalam bersaing dalam proses pembelajaran sangat diutamakan. Dan ini sama halnya dengan pendidikan dalam hal Al-Qur'an yang mana di ketahui sebagai kitab yang di sucikan, dan di dalamnya mengandung petunjuk kehidupan umat Islam. oleh karena itu, kewajiban juga untuk menanamkan kecintaan terhadap kitab mukjizat ini kepada penerus-penerus agama sejak sedini mungkin. ${ }^{4}$

Penduduk Indonesia di dominasi oleh orang yang beragama Islam. Akan tapi Hasil Riset dari Institut Ilmu Al-Qur'an (IIQ) meneliti bahawasannya 65 persen penduduk indonesia yang beragama islam buta akan bacaan huruf Alqur'an. Serta hasil penilaian dari Dewan Dakwah Islamiyah Indonesia (DDII) mengatakan bahwa fenomena seperti ini harus menjadi perhatian tersendiri karena akibat dibelakangnya yang fatal yaitu bisa membuat generasi islam di Indonesia semakin kurang interaksinya dengan AlQur'an sehingga generasi ini akan menjadi malas untuk belajar dan mengamalkan AlQur'an. Dengan banyaknya metode

${ }^{4}$ IAIN Raden And Intan Lampung, "Paradigma Kontemporer Sistem Pembelajaran Pendidikan Keguruan Madrasah Ibtidaiyah (PGMI) 1", 3 (2016), 1-22. pembelajaran Al-Qur'an saat ini yang ditujukankan untukanak usia dini metode iqro', metode ummi, metode tilawati dan yang memakai bulpen elektronik. ${ }^{5}$ Dan salah satu telah hadir Lembaga Ka'Uqoy Privat.

Hadirnya Lembaga Ka’Uqoy Private di tengah-tengah masyarakat membawa angin segar tersendiri bagi keluarga wali murid yang bingung untuk mencari guru Al-Qur'an. Dengan suguhan kreatifitas pengajar yang sudah disiapkan sebelum terjun untuk mengajar dengan cara latihan (training) secara matang setelah tahap perekrutan dilakukan yang mana materinya diberikan langsung oleh sang pendirinya. Sehingga menjadikan anak-anak usia dini cepat menangkan dengan tidak mudah bosan dalam proses belajar mengajar.

Oleh karena itu, penulis mengusung tema ini, agar para pengajar Al-Qur'an bisa dengan benar mengajarkan ilmu Al-Qur'an terutama pada anak usia dini yang tidak lagi monoton dan membosankan tapi membangun keceriaan sehingga membuat anak tertarik dan senang dalam memperlajari Al-Qur'an. Kelak akhirnya presentase orang islam Indonesia di masa mendatang bisa lebih banyak yang bisa membaca dan mendalami kitab suci umat islam yang bisa menjadi petunjuk

5Prosiding Al, Hidayah Pendidikan, And Agama Islam, "Implementasi Metode Pembelajaran Alquran Bagi Santri Usia Tamyiz Di Kuttab AlFatih Bantarjati Bogor", 1, 179-91. 
mengarungi hidup dan mensyafa'ati ketika kita sudah meninggal.

\section{Kajian Teori}

\section{Pengertian pembelajaran Al-Qur'an}

Agama Islam adalah agama yang memperhatikan secara detail kehidupan manusia. Sehingga benar adanya kalau Islam ialah agama yang rabmatan lil alamin kelebihan dalam memperhatikan melebihi kelebihan dalam undang-undang yang di aturkan dalam seluruh negara. Perhatian Islam terhadap anak diusia dini sangat terlihat dari mulai di kandungan seorang ibu boleh membatalkan puasa ketika hamil. Jika saja ibu inikhawatir akan kesalamatan dan kesehatan sang buah hati yang di kandungnya ataupun yang disusuinya. Itulah bukti Islam yang sangat memperhatikan kehidupan manusia dari dalam kandungannya hingga manusia menua.

Dengan ini berarti sudah jelas bahwasannya pendidikan sejak dini itu sangat penting adanya, karena pendidikan usia dini lebih banyak keberhasilannya dan juga akan mempengaruhi tumbuh kembangnya setelah anak tersebut dewasa. ${ }^{6}$

"Abdul Hafiz dab Hasni Noor, "Pendidikan Anak dalam Prespektif Alqur'an", Vol', 1.2 April (2016).
Apalagi yang diajarkan itu ialah hal utama yaitu pedoman kehidupan yang langsung dari sang pencipta manusia. Mengajarkannya sejak dini adalah sebuah keharusan serta banyak firman Allah yang terdapat dalam Al-Qur'an tentang keharusan dalam mendidik anak usia dini. Seperti contohnya mengajarkan atau mendidik anak tentang berdikari yang terdapat pada Q.S Al-Anbiya ayat 78

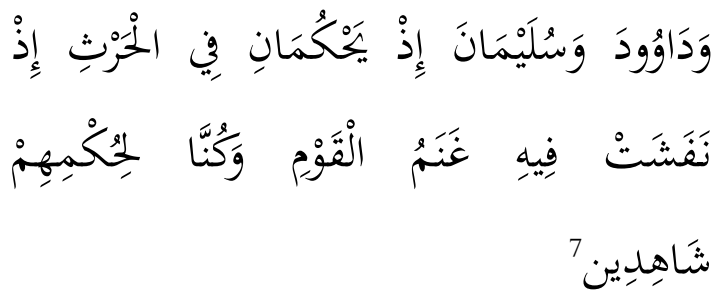

"Dan ingatlah kisah Daud dan Sulaiman, di saat keduanya memberi sebuah keputusan tentang tanaman, disebabkan tanaman yang telah dirusak kambing-kambing milik kaumnya, dan adalah Kami menyaksikan keputusan yang ditetapkan oleb mereka itu" ${ }^{8}$

Dan mengajarkan anak tentang beribadat yang terdapat pada Q.S AlAnbiya ayat 32

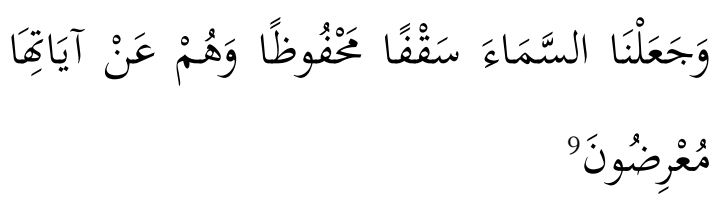

"Dan Kami menjadikan langit itu sebagai atap yang terpelihara, sedangkan mereka

\footnotetext{
${ }^{7}$ Departemen Agama RI, Al-Qur'an Dan Terjemahnya, 328.

${ }^{8}$ Departemen Agama RI, 328.

${ }_{9}^{9}$ Departemen Agama RI, 324.
} 


\section{Nur Shofiyah dan Masruchan}

berpaling dari segala tanda-tanda (kekuasaan Allab) yang terdapat ada padanya,"10

Anak usia dini sebagaimana yang kita ketahui bahwa mereka masih sangat butuh namanya pendampingan dan pengarahan untuk mendidik, membina dan membentuk akhlaknya. Karena kebiasaan oleh sang pendidik (guru, ustadz atau ustadzah) adalah hal yang akan di tiru pertama oleh sang anak didikannya. Jika kebiasaan yang di tanamkan itu keras kepala, pemarah, dengki, tidak sabaran, rakus, selalu tergesagesa, gegabah dalam mengambil sesuatu maka hal itu akan sangat sulit dirubah kelak ketika anak tersebut dewasa. Karena anak usia dini sangat cepat dalam menangkap pembelajaran dan sangat sulit bila diruah kebiasaanya. Oleh karena itu Pembelajaran Al-Qur'an harusnya di ajarkan kepada anak di usia sedini mungkin karena selain AlQur'an adalah kitab petunjuk di dalamnya ada banyak bimbingan Akhlak yang patut diajarkan kepada anak. ${ }^{11}$

Usaha yang dilakukan dengan sadar dalam mendidik Al-Qur'an ialah aktifitas dalam pembelajaran Al-Qur'an yang didalamnya meliputi membaca, menulis, hingga mempelajari tajwid yaitu hukumhukum bacaan yang terdapat didalam AlQur'an yang mana tujuan untuk mempelajarinya tak lain karena agar ketika

${ }^{10}$ Departemen Agama RI, 324.

${ }^{11}$ Abdul Hafiz dab Hasni Noor, "Pendidikan Anak dalam Prespektif Alqur'an”, 9. membaca Al-Qur'an secara tepat dan sempurna. Dan dari hal ini tidak hanya pelajaran terkait saja yang akan didapatkannya melainkan juga akhlak dan sikap ketelatenan, kesabaran hingga ketelitian yang diasah untuk anak usia dini. Hingga terciptanya karakter yang Qur'ani seperti yang diinginkan oleh para pendidik yang bersangkutan. ${ }^{12}$

Adapun dasar yang menyatakan bahwa Al-Qur'an merupakan pembelajaran yang sempurna ialah pada Q.S Al-An'an ayat 38 yaitu:

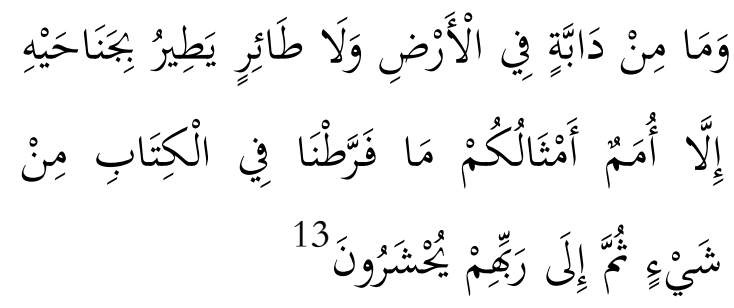

Artinya: "Dan tidak ada seekor binatang pun yang ada di bumi dan burung-burung yang terbang dengan kedua sayapnya, melainkan semuanya merupakan umat-umat seperti kamu. Tidak ada satupunyang yang kami luputkan di dalam kitab. Kemudian kepada Allah mereka di kumpulkan". ${ }^{14}$

Secara gamblang dijelaskan bahwasannya Al-Qur'an itu sumber yang paling utama bagi segala perkara yang selama ini dibutuhkan oleh seorang

${ }^{12}$ Sadiah, Rahendra Maya, and Unang Wahidin, "Implementasi Model Pembelajaran Dalam Pemberantasan Buta Huruf Al-Quran di Majelis Taklim Nurul Hikmah Kampung Situ Uncal Desa Purwasari Kecamatan Dramaga Kabupaten Madiun', Prosa PAI (Prosiding Al Hidayah: Pendidikan Agama Islam), 2018, 1-18.

${ }^{13}$ Departemen Agama RI, Alqur'an Dan Terjemahnya, 132

${ }^{14}$ Departemen Agama RI, 123 
manusia, baik dalam berbagai penelitian keilmuan, penelitian pengetahuan serta suatu yang bersinggungan dengan kebutuhan hidup manusia. Sedangkan kewajiban belajar oleh manusia adalah sesuatu yang memang harus di fahami. Salah satu materi yang paling pokok adalah membaca. Dan apa itu yang harus di baca? Atau apa itu yang harus di pelajari? Itu adalah kitab suci Al-Qur'an. ${ }^{15}$ Sebagaimana Allah menurunkan kalamullah untuk yang pertama kali yaitu Q.S Al-Alaq pada ayat 1 sampai dengan 5 yang berbunyi :

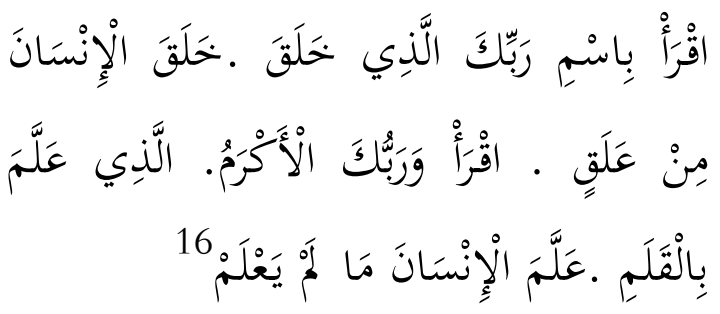

Artinya: "Bacalab dengan menyebut nama tubanmu yang menciptakan, Dia yang menciptakan manusia dari segumpal darah, bacalab dan tubanmulab yang maha Muliayang mengajar dengan pena, Dia mengajarkan manusia apa yang tidak di ketabuinya. $^{17}$

Ayat di atas sebagaimana kita tahu adalah ayat yang pertama kali diterima Rsulullah dari Allah SWT melalui pelantaran malaikat jibril di sebuah gua

${ }^{15}$ Prosiding Al, Hidayah Pendidikan, And Agama Islam, "Implementasi Metode Pembelajaran Alquran Bagi Santri Usia Tamyiz Di Kuttab AlFatih Bantarjati Bogor", 10.

${ }^{16}$ Departemen Agama RI, Alqur'an Dan Terjemahnya, 597.

${ }^{17}$ Departemen Agama RI, 597. yang terkenal sebutannya dengan gua Hira. Dan Ayat ini terkenal dengan ayat yang memerintah untuk membaca dan mencari ilmu. $^{18}$

\section{Filsafat Kontruksionisme}

Filsafat kontruksionisme terdiri dari dua suku kata yaitu filsafat dan kontruksionisme. Filsafat adalah studi mengenai fenomena kehidupan serta pemikiran manusia secara kritis dan dijabarkan dalam konsep yang mendasar. Filsafat dialami dengan mengutarakan masalah secara persis, memberi argumentasi, mencari solusi dan alasan yang pas untuk solusi tersebut. Bukan alami dari eksperimen-eksperimen atau percobaan-percobaan. Dan filsafat pendidikan ialah ilmu yang didalamnya mengandung jawaban-jawaban pada lapangan pendidikan dan merupakan suatu pengaplikasian dari analanisa filosofis terdahap lapangan pendidikan. Semantara itu maksud dari filsafat pendidikan Islam ialah suatu formula filsafat yang mana di dalamnya mengandung filsafat pendidikan yang berasas dari sumber-sumber Islam, baik itu sumber-sumber yang sifatnya historis yaitu ( berasal dari jejak-jejak penelusuran filsafat pendidikan tentang

${ }^{18}$ Prosiding $\mathrm{Al}$, Hidayah Pendidikan, And Agama Islam, "Implementasi Metode Pembelajaran Alquran Bagi Santri Usia Tamyiz Di Kuttab AlFatih Bantarjati Bogor", 11. 
Islam) maupun normatif yaitu (yang berasal dari wahyu berupa Al-Qur'an dan Hadist). ${ }^{19}$

Sedangkan kontrusionisme berasal dari susunan kata kontrukstiv dan isme. Konstruktiv yang artinya membina, membangun dan memperbaiki dan untuk isme dalam kamus besar bahasa Indonesia yang mempunyai makna paham atau aliran. Kontrukstivisme adalah aliran yang filsafat pengetahuan yang menekankan bahwa ilmu pengetahuan kita merupakan hasil konstruksi kita sendiri. Dan penerapan dalam proses pendidikan aliran kontruktivisme menyajikan kebebasan kepada peserta didik untuk aktif merangkai atau membangun kebermanaansesuai dengan pemahaman yang sudah mereka miliki. Perlunya rangkaian kesadaran akan makna pengetahuan tidak bersifat stabil. Akan tetapi sifat kontemporer akan selalu bergantung pada persepsi subyektif perorangan dan perorangan yang berpengetahuan mengisterpertasikan serta membangun (mengkontruksi) suatu kenyataan berdasarkan pengalaman dan hubungannya dengan lingkungan. Ilmu pengetahuan adalah ilmu yang mampu

${ }^{19}$ Yunita Furi Aristyasari and Restu Faizah, 'Membedah Corak Filsafat Pendidikan Mubammadiyah (Telaab Konsep Pendidik Mubammadiyah)', 5.2 (2020) <https://doi.org/10.25299/al-thariqah. 2020. $\operatorname{vol5}(2) .5872>$. memecah segala macam permasalahan atau persoalan yang ada. ${ }^{20}$

$$
\text { Manusia }
$$

mengkontruksi

pengentahuannya melalui fenomena, objek, lingkungan dan pengalamannya. Dan pengetahuan itu di anggap nyata kebenarannya bila sudah dinyatakan memecagkan sebuah permasalahan. Kontruksionisme dianggap sebuah filsafat yang mana pengetahuan itu adalah hasil dari kontruksi atau bentukan manusia itu sendiri. Mattews mengelompokkan dua tradisi besar dari kontruktivisme, yaitu kontruktivisme sosioligi dan kontruktivisme psikologis. ${ }^{21}$

Konstruktivisme sosioslogi ialah pengetahuan yang di bangun lebih yang di tujukan kepada masyarakat. Sedangkan untuk konstruktivisme psikologisialah bertitik tolak dari pengetahuan anak dalam membangun pengetahuannya. ${ }^{22}$

Dan untuk implikasinya sendiri filsafat kontruktivisme terhadap pendidikan mencangkup apa itu tujuan dari pendidikan itu. Yaitu, untuk membantu generasi muda menjadi generasi yang sempurna dan utuh, yang mampu bersaing di segala bidang.

${ }^{20}$ IAIN Raden dan Intan Lampung, 'Paradigma Kontemporer Sistem Pembelajaran Pendidikan Keguruan Madrasah Ibtidaiyah (PGMI)", 7.

${ }^{21}$ Suparno, Filsafat Konstruktivisme dalam Pendidikan, (Yogyakarta: Kanisius, 1997), 43.

${ }^{22}$ Ahmad Nizar Rangkuti, "Konstruktivisme Dan Pembelajaran Matematika", Darul Ilmi, 2.2 (2014),6176<http://jurnal.iainpadangsidimpuan.ac.i d/index.php/DI/article/view/416>. 
Baik dari segi ilmu pengetahuan, moral, kepekaan terhadap lingkungan, budi luhur, beriman serta masih banyak lagi. Mudahnya seseorang masuk kedalam sebuah masyarakat itu salah satunya dengan pendidikan. Pendidikan juga membantu anak bangsa menjadi warga negara yang baik serta bertangung jawab. Dalam arian pendidikan menjadi sumbangsih tersendiri bagi berkembangnya sebuah bangsa. Dan bagi kaum kontrukstivis, belajar merupakan proses mengkontruksin pengetahuan yang mana prosesnya dilakukan secara pribadi dan terkadang bersosial. Bukanlah proses untuk memindahkan dari pendidik terhadap peserta didik namun lebih kepada peranan aktif. Dalam artian mengajar ialah sebuah bentuk belajar sendiri yang di dalamnya terdapat pencarian makna, kejelasan, pengetahuan dan sikap kritis. ${ }^{23}$

\section{Lembaga Ka' Uqoy Private}

Ka Uqoy Private Tabsin Whith Fun Learning dirintis sejak tahun 2015. Ka Uqoy Private, diambil dari nama pendiri Ka Uqoy sendiri yaitu (Uqoy Batul Fajariyah). Ka Uqoy datang dari keluarga yang memiliki perhatian pada dunia pendidikan dan terutamanya itu pendidikan agama Islam. Ayah kandung dari Ka Uqoy menjabat sebagai seorang kepala sekolah

${ }^{23}$ Ahmad Nizar Rangkuti, "Konstruktivisme Dan Pembelajaran Matematika", 8 yang di tugaskan di salah satu Sekolah Dasar Islam Swasta di Jakarta Selatan serta sebagai tokoh agama dilingkungan tempat tinggalnya. Tidak hanya belajar di sekolah umum saja. Ka Uqoy juga pernah belajar di pendidikan non formal yaitu di Pondok Pesantren selama 6 tahun, barulah setelah itu Ka Uqoy melanjutkan sekolah umum di Universitas Muhammadiyah Jakarta dengan mengambil jurusan kuliah sesuai dengan fasion latar belakangnya yaitu Pendidikan Agama Islam. ${ }^{24}$

Ka Uqoy memulai kiprahnya mengajar private mengaji anak-anak semenjak beliau lulus dari pendidikan di Pesantren, Ka Uqoy mengajarkan private berbarengan dengan kegiatannya menuntut ilmu (kuliah). Dan setelah Ka Uqoy menyelesaikan pendidikannya di Strata satu Universitas dengan jurusan Pendidikan Agama Islam. Ka Uqoy mengabdikan dirinya untuk berdedikasi ke putra-putri bangsa Indonesia dengan cara mengajarkan pendidikan Agama Islam di salah satu Institusi Sekolah Islam Swasta berwawasan global dan berbasis inklusi yang memiliki metode Fun Learning selama 8 tahun. Dan tidak berhenti di situ saja. Akan tetapi akan semangat membagi ilmu yang di dapat Ka Uqoy, beliau juga tetap menjalani dan

\footnotetext{
${ }^{24}$ Uqoy Batul Fajariyah, Arsip kelembagaan kaUqoy Private.
} 
berusaha untuk menjaga keistiqomahannya mengajar mengaji yang memang sudah di lakukannya semenjak ka Uqoy mengenyam pendidikan di perkuliahan. ${ }^{25}$

Berbekal pengalaman-pengalaman yang luar biasa tersebut. Maka, dari sinilah cikal bakal berdirinya lembaga ka Uqoy ini berdiri. Di mana ka Uqoy berusaha untuk mencoba mengenalkan metode yang inspiratif danyang paling mempengaruhi yaitu " Bagaimana agar anak usia dini mau mengenal, dan mempelajari Al-Qur'an dan menerimanya dengan rasa bahagia serta menyenangkan. Sehingga tidak terkesan belajar untuk mengejar waktu saja dalam menguasainya lalu berhenti dan tidak lagi ada keistiqomahan dalam mempelajari AlQur'an dan Agama Islam. Akan tetapi $\mathrm{Ka}$ Uqoy ingin mencetak anak-anak yang terus-menerus dan selalu istiqomah belajar mengaji dengan cara yang menyenangkan dan tidak membosankan. Karena ilmu Agama Islam adalah Ilmu sepanjang Hayat dikandung badan. Dengan demikian banyak anak-anak yang kini selalu menanti kehadiran kakak-kakak pengajar untuk sama-sama belajar mengenal huruf-huruf hijaiyah, doa-doa harian, surat-surat dalam Al Qur'an dan kisah-kisah teladan islami dengan cara yang menyenangkan dan membahagiakan. ${ }^{26}$

${ }^{25}$ Uqoy Batul Fajariyah

${ }^{26}$ Uqoy Batul Fajariyah
Dan hasil wawancara pada salah satu pengajar dari Ka Uqoy Private ini mengatakan bahwasannya dahulu pengajar dari Ka Uqoy Private hanya saja dari kalangan keluarga saja yang memang sudah terkenal Agamis. Dan karena semakin banyaknya permintaan dari wali murid untuk ikut bergabung dalam private tersebut. Maka, mulailah lembaga Ka Uqoy Private ini membuka lowongan untuk membantu menyebarkan ilmu agama dengan cara perecrutment pengajar yang dalam kriteria-kriteria yang sudah ditetapkan dalam lembaga yang mana salah satunya lulusan pondok pesantren minilmal 3 tahun, kreatif, suka terhadap anak-anak dan sopan santun. Untuk pembukaan pertama di Jabodetabek saja, lalu cabang yang dibuka pertama kali di Bandung, kedua di Surabaya, ketiga di Bali dan barubaru ini baru buka kembali cabangnya di Yogyakarta. ${ }^{27}$

Termasuk dalam perkembangan kelembagaan yang cepat dalam kurun waktu lima tahun saja, hampir seluruh wilayah jawa sudah dijamah sama lembaga ini. Adapun lembaga Ka Uqoy private ini tidak hanya mengajar pada kalangan menengah saja namun juga kalangan artis pun pempercayakan putra putri mereka belajar mengaji dengan pengajar dari $\mathrm{Ka}$ Uqoy Private, di antaranya putra putri dari

\footnotetext{
${ }^{27}$ Wawancara online dengan salah satu pengajarnya di Surabaya 17 Januari 2021 (16.07)
} 
Zaskia Adya Mecca mulai dari putri pertama Kanna Syibilla Bramantyo, lalu Bhai Kaba Bramantyo, lalu Kala Madali Bramantyo dan Bhre Kata Bramantyo. Lalu ada putri Aqilah dari Artis Indonesia Ayu Dewi, juga Noah Sinclair putra dari pasangan artis dan penyanyi Ashraf Sinclair dan Bunga Citra Lestari.

\section{Metodologi Penelitian}

Jenis penelitian yang digunakan adalah jenis penelitian kualitatif deskriptif. Penelitian kualitatif deskriptif adalah suatu penelitian yang berusaha mendeskripsikan data yang didapatkan dari lapangan dalam bentuk kata-kata dan memaparkan realitas secara utuh, asli, cermat dan faktual. ${ }^{28}$ Maka penelitian ini akan menggambarkan praktik serta mendeskripsikan Paradigma kontemporer. Sistem pembelajaran al qur'an Pada anak usia dini di lembaga tahsin qur'an Kauqoy Private.

Penelitian ini akan menggunakan tiga teknik pengumpulan data dalam Metode analisis deskriptif, di antaranya:

\section{Observasi}

Teknik ini merupakan salah satu teknik utama dalam penelitian Living. Observasi adalah pengamatan serta pengelihatan khusus pada objek dalam

${ }^{28}$ Fadjrul Hakam Chozin, Cara Mudah Menulis Karya Ilmiab (TK: Alpha, 1997), 44. rangka memahami serta mencari bukti terhadap fenomena sosial-keagamaan selama beberapa waktu tanpa mempengaruhi fenomena yang diamati. Peneliti akan menunjukan identitas dengan tujuanmendapatkan data dengan mudah namun ada saat peneliti mendatangi objekpenelitian tanpa menunjukkan identitas, agar informasi yang didapat tidak direkayasa. Dengan teknik ini, akan diperoleh data yang akurat terkait bagaimana praktik pengajaran Al-Qur'an di lembaga Ka Uqoy Private.

\section{Wawancara}

Wawancara adalah suatu alat untuk mengumpulkan data yang efektif dan efisien. $^{29}$ Menggunakan teknik ini data mengenai pengajaran atas Alquran sebagaimana pengajaran dyang di terapkan oleh lembaga Ka Uqoy Private. Peneliti boleh menggunakan alat perekam dan kamera sebagai pendukung proses pengumpulan data.

\section{Dokumentasi}

Dokumentasi merupakan teknik pengumpulan data menggunakan alat bantu berupa tape recorder, alat potret, video shooting, kamera digital dan handycam. Sebagai teknik penyempurna, dokumentasi di gunakan untuk menggambarkan bagaimana

${ }^{29}$ Supranto, Metode Riset Aplikasinya dalam Pemasaran (Jakarta: Lembaga Riset Fak. Ekonomi Universitas Indonesia, 1986), 2 
pengajaran Alquran secara fun learning di terapkan di lembaga Ka Uqoy Private.

Upaya untuk mengolah data peneliti akan menggunakan tiga tahapan teknik analisis data, di antaranya: Tahapan reduksi data, Tahapan penyajian data danTahapan verifikasi data. ${ }^{30}$

\section{Hasil Pembahasan}

Paradigma Kontemporer Sistem

Pembelajaran Al Qur'an Pada Anak

Usia Dini Di Lembaga Tahsin Qur'an Ka'Uqoy Private

Menurut penelitian, Pendekatan dalam pembelajaran Al-Qur'an itu penting untuk diterapkan. Dalam hal ini bertujuan agar peserta didik menjadi kebiasanya dengan bacaannya sehingga pada akhirnya peserta didik akan mudah dalam melancarkan bacaannya. Pendekatan dengan cara fun learning ini secara tidak langsung terjadi proses peserta didik yang menanamkan rasa suka dan kecintaannya kepada apa yang sedang di pelajarinya saat itu. Sehingga, tidak ada kemalasan atau akan terus senang bila peserta didik belajar dengan kitab Al-Qur'an tersebut. Karena pengenalan awalnya peserta didik terima dengan perasaan yang senang.

${ }^{30}$ Anggia Nahla Prasetya, "Resepsi Masyarakat Pada Alquran Sebagai Shifa<' Bagi Kesembuhan Pasien (Studi Living Quran di Rumah Sakit Islam Jemursari Surabaya”, Skripsi Ilmu alQuran dan Tafsir Fakultas Ushuluddin dan Filasafat UIN Sunan Ampel, 2020.

\section{Perbedaan sistem di lembaga Ka'Uqoy}

\section{Private dengan lembaga lain}

Berkaitan dengan metode atau sistem pembelajaran Al-Qur'an dari lembaga $\mathrm{Ka}$ Uqoy Private ini, peneliti melakukan wawancara secara online karena masih dalam keadaan musim pandemi dan psbb di daerah jawa dan bali yang tidak memungkinkan untuk bertemu dengan tatap muka, maka wawancara di lakukan dengan bantuan aplikasi yang mana menghubung langsung pada salah satu pengajar dari koordinasi dari lembaga $\mathrm{Ka}$ Uqoy Private dari cabang kota metropolitan kedua yaitu Surabaya. Mengatakan kalau lembaga Ka Uqoy Private ini untuk metode pembelajaran AlQur'annya menggunakan metode Fun Learning. Yaitu pada pengajar di tuntun untuk menyiapkan bahan ajar yang menyenangkan ketika sebelum terjadinya belajar mengajar, dan harus sesuai dengan silabus yang sudah di bserikan sama lembaga Ka Uqoy Private. Bahan ajar ini maksudnya ialah sebuah alat peraga yang bagi anak-anak usia dini itu sangat menarik seperti dalam contoh berikut.

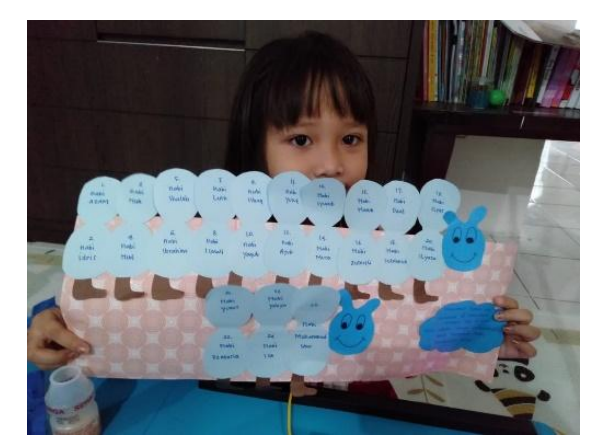

Sabia dari pengajar kak putri Surabaya 


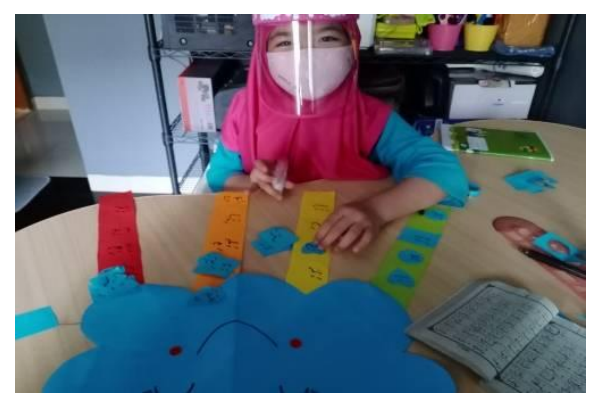

Izzarasia dari pengajar kak Mella

Jakarta Timur

Untuk tercapainya sebuah pembelajaran yang sesuai dengan keinginan. Maka pembelajaran tersebut seharusnya penting untuk memiliki metode pembelajaran dan khususnya untuk belajar kitab suci Al-Qur'an yang langsung dari pencipta. Pemilihan metode dan penanaman rasa suka terhadapnyalah yang lebih dulu dikenalkan kepada anak-anak di usia dini yang belum mengerti akan hukum atasnya. Begitu pula seorang ustadz ataupun ustadzah dalam pengajar Ka Uqoy Private di tuntut untuk kreatif dan energic dalam setiap mengajar. Agar anak-anak usia dini ini sebelum mengenal Al-Qur'an semakin dalam sudah tertanam dahulu rasa suka dan senang terhadap apa yang akan di pelajarinya.

Gambar di atas merupakan salah satu contoh dari peraga yang di buat oleh para pengajar Ka Uqoy Private yang dilakukan secara tatap muka atau pengajar datang langsung kekediaman sang wali dari anakanak usai dini tersebut. Hal itu tentu akan sangat berbeda jika di bandinghkan dengan pengajaran para Lembaga yang menerapkan sistem mengajar Al-Qur'an itu secara berjamaah dan kelompok atau dalam masyarakat itu TPQ ataupun TPA. Sehingga sangat kurang intens bagi anak yang membutuhkan perhatian yang lebih. Menurut penelitian, private atau pengajaran yang di lakukan dengan perorangan itu akan berdampak pada kemampuan dan kualitas membaca Al-Qur'an yang dimiliki dan akan lebih terlihat kesempurnaankesempurnaan bacaanya.

\section{Sistem Pembelajaran pada Musim Pandemi Oleh Lembaga KaUqoy Private}

Dan ketika Indonesia dalam keadaan PSBB pasca dari pandemi, sama sekali tidak mengurangi kekreatifan dari para pengajar dan juga lembaganya untuk mensyiarkan Agama Islam. Mereka membuat pembelajaran terus berjalan dengan meanfaatkan teknologi yang ada. Dengan menggunakan aplikasi Zoom, atau video whatshab serta aplikasi-aplikasi yang mendukung untuk di gunakannya mengajar secara virtual. Akan tretapi dari kebanyakan pengajar menggunakan aplikasi zoom sehingga di situ para pengajar tidak lagi menggunakan bahan peraga yang di buat mengajar, melainkan membuat power point atau share video yang sesuai dengan materi 
yang di pelajarinya seperti contoh pembelajaran daring yang sudah di jalani hampir 8 bulan terakhir ini:

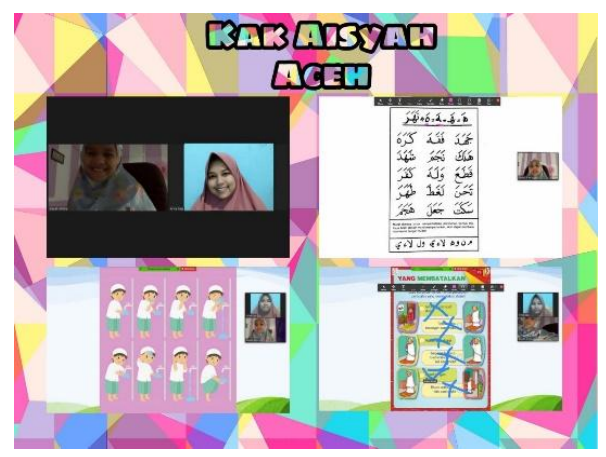

Aisyah Aceh dari pengajar kak Arina Surabaya. Pembelajaran daring

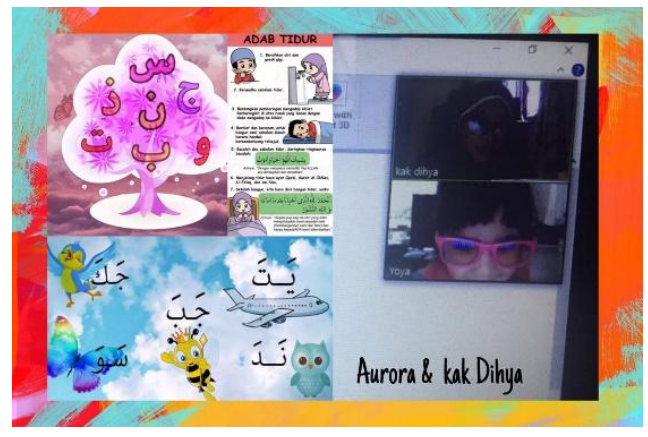

Aurora dengan kak Dihya dari Yogyakarta.

Adapun untuk rangkaian prosesnya.

Kebanyakan anak usia dini yang di ajarkan berkisar dari umur tiga tahun an ke atas jadi pertama kita akan memberi salamn sapa dan berdo'a. Setelah itu di tanya kabar hari ini untuk merekatkan pengajar dengan si anak tersebut dan disini juga melatih anak bisa mengungkapkan isi dari hatinya tanpa perlu pelampiasan dengan marah, sehingga disini si anak seakan mempunyai posisi untuk di dengarkan curhatannya. Dan itu di lakukan sekitar lima menit habis itu kemateri dengan alat peraga kalau offline, sedangkan kalau online, pengajar membuka bahan power point yang sudah disiapkan sebelumnya. Sehabis mengikuti materi dengan baik, pengajar tidak boleh diam tetapi di barengi dengan wawasan tentang kaidah, fiqih dan akhlak budi perti yang penyampaiannya dengan cara menyanyi, karena lagu atau nyanyian itu materi yang sangat mudah sekali di tangkap sama anakanak usia dini ketika sedang belajar.

Dan biasanya dalam akhir waktu pembelajaran anak-anak usia dini ini paling suka dengan hadiah. Jadi, lembaga $\mathrm{Ka}$ Uqoy Private menyarankan untuk memberi hadiah walaupun kecil tetapi dengan hadiah biasanya anak-anak usia dini juga akan ikut ketagihan untuk terus mengulang-ulang dalam mempelajari Al-Qur'an. Dan juga menambah semangat di anak tersebut. Hal ini dibenarkan adanya oleh salah satu pengajar Ka Uqoy private dari Surabaya yaitu ustadzah Srah dari pondok gede yang mengajar seorang anak yang bernama Aina. Pengajar membuktikan dengan hadil apabila di beri sanggupan hadiah kecil setelah mengaji, maka semangat Aina akan bertambah dan mengajinya akan lebih banyak serta nagih mengaji lagi besoknya.

Tetapi terkadang juga hal tersebut tidak di butuhkan sepenuhnya karena kalau mereka sudah termotivasi dengan pengajarnya dan pelajarannya. Hal semacam memberikan hadiah adalah suatru usaha kecil bila si anak usia dini ini dalam 


\section{An-Nisa' : Jurnal Kajian Perempuan \& Keislaman \\ Vol. 14, No. 1, April 2021 \\ p-ISSN : 2086 -0749 \\ e-ISSN : 2654-4784}

keadaan mood atau keadaan yang yang kurang mendukungnya untuk belajar. Seperti anak yang bangun tidur dan langsung di suruh belajar, kebanyakan anak usia dini pasti moodnya kurang baik. Nah, disini peran hadiah kecil tersebut di keluarkan atau di janjikan. Hadiah tersebut tidak hadiah yang harganya mahal namun biasanya berupa mainan kecil atau stiker.

Dan setelah mengajinya sudah sampai pada menit ke 60 maka sang pengajar akan memimpin untuk menyelesaikan proses belajarnya. do'a pulang yang di bacakan bersama lalu salam perpisahan. Serta tidak lupa pengajar sebelum pulang mengisi buku prestasi apa saja atas perkembangan anak usia dini tersebut pada buku prestasi yang sudah di persiapkan sama lembaga, dan buku tersebut akan ditinggal dirumah wali murid. Gunanya agar wali murid bisa memantau perkembangan belajar putra-putrinya.

Menurut penelitian, private atau pengajaran yang di lakukan dengan perorangan itu akan berdampak pada kemampuan dan kualitas membaca AlQur'an yang dimiliki dan lebih terlihat kesempurnaan tajwidnya ketika memabacanya. ${ }^{31}$

${ }^{31}$ Sadiah, Rahendra Maya, and Unang Wahidin, "Implementasi Model Pembelajaran Dalam Pemberantasan Buta Huruf Al-Quran Di

\section{Simpulan}

Sistem pembelajaran Al-Qur'an anak usia dini pada lembaga Ka Uqoy Private dapat disimpulkan sebagai berikut:

1. Pendekatan yang diajarkan dalam pembelajaran Al-Qur'an di lembaga Ka Uqoy Private adalah pendekatan individual.

2. Metode yang digunakan dalam pembelajaran Al-Qur'an di lembaga Ka' Uqoy Private adalah metode Fun Learning.

3. Media pengajaran yang digunakan oleh lembaga Ka'Uqoy private adalah peraga pengajaran tentang Al-Qur'an yang semenarik mungkin.

4. Sumber atau buku yang digunakan untuk pengajaran Al-Qur'an adalah Tahsin Al-Qur'an melalui jilid, juz'amma dan buku tentang do'a-do'a keseharian.

5. Proses kegiatan pengajaran pada lembaga $\mathrm{Ka}$ Uqoy Private adalah kegiatan awal, kegiatan inti dan kegiatan akhir.

6. Pemberian hadiah sebagai apresiasi setelah dia belajar serta atas semangatnya mempelajari Al-Qur'an.

Majelis Taklim Nurul Hikmah Kampung Situ Uncal Desa Purwasari Kecamatan Dramaga Kabupaten Madiun", 16. 
Dan yang bisa sebagai pengembali mood anak yang masih dalam usia dini.

\section{Daftar Pustaka}

Chozin, Fadjrul Hakam. Cara Mudah Menulis Karya Ilmiah. TK: Alpha, 1997.

Departemen Agama RI. Alquran Dan Terjemahnya. Jakarta: Kemenag RI, 1998.

Faizah. Yunita Furi Aristyasari and Restu, "Membedah Corak Filsafat Pendidikan Muhammadiyah" (Telaah Konsep Pendidik Mubammadiyab)', 5.2 (2020).

Lampung, IAIN Raden dan Intan "Paradigma Kontemporer Sistem Pembelajaran Pendidikan Keguruan Madrasah Ibtidaiyah (PGMI) 1", 3 (2016).

Noor, Abdul Hafiz dab Hasni, "Pendidikan Anak dalam Prespektif Alqur'an", Vol', 1.2 April (2016).

Prasetya, Anggia Nahla. "Resepsi Masyarakat Pada Alquran Sebagai Shifa<' Bagi Kesembuhan Pasien" (Studi Living Quran di Rumah Sakit Islam Jemursari Surabaya). Skripsi Ilmu Alquran dan Tafsir Fakultas Ushuluddin dan Filasafat UIN Sunan Ampel, 2020.

Prosiding Al, Hidayah Pendidikan, And Agama Islam, "Implementasi Metode Pembelajaran Alquran Bagi Santri Usia Tamyiz Di Kuttab Al-Fatih Bantarjati Bogor", Dosen Prodi Pendidikan Agama Islam STAI Al Hidayah Bogor A . Pendahuluan Alquran Menurut M . Sarbini Adalah Kalamullah S . W . T . (Kata-Kata Allah S. W', T.

Rangkuti, Ahmad Nizar, 'Konstruktivisme Dan Pembelajaran Matematika', Darul Ilmi, 2.2 (2014).

Supranto. Metode Riset Aplikasinya dalam Pemasaran. Jakarta: Lembaga Riset Fak. Ekonomi Universitas Indonesia, 1986.
Suparno, Filsafat Konstruktivisme dalam Pendidikan, Yogyakarta: Kanisius, 1997.

Wahidin, Sadiah, Rahendra Maya, dan Unang "Implementasi Model Pembelajaran Dalam Pemberantasan Buta Huruf Al-Quran di Majelis Taklim Nurul Hikmah Kampung Situ Uncal Desa Purwasari Kecamatan Dramaga Kabupaten Madiun", Prosa PAI (Prosiding Al Hidayah: Pendidikan Agama Islam), 2018.

Fajariyah, Uqoy Batul, Arsip kelembagaan kaUqoy Private.

Wawancara online dengan salah satu pengajarnya di Surabaya 17 Januari 2021 (16.07) 